\title{
THE COLLECTIVE LABOUR AGREEMENT AND ITS AGENCY OF ENFORCEMENT
}

\author{
HENRY L. MOLOT*
}

A growing spirit of collectivism in our present age has evoked in consequence this apparent dilemma: a contract between employer and a trade union has supplanted, for all intents and purposes, the individual hiring contract that formerly had governed the relations of master and servant, but in so doing it has posed the problem of whether, and if so, how this employer and employee might be able to enforce their rights and obligations inter se. As a prelude to the discussion of the Canadian law on the subject, a brief survey of the American scene will serve to construct the framework for the analysis then to follow.

If a trade union, purporting to represent all the employees in a unit but unable to assert that all of these persons are its members or have given it full authorization to make terms, should enter into a collective agreement with that unit's employer, how are an employee and the employer to enforce its terms against the others? American courts, without the aid of statutes, have been more successful in handling the obstacles that plagued attempts to apply rules of the common law with any rigour. Nevertheless, the rationales propounded in the United States have been applied most often in actions brought by the employee and have failed to appreciate that they might not support a reciprocal suit brought by his master. The most prominent basis for upholding an employee's claim characterizes the plaintiff as "third party beneficiary", which assumes the agreement to be a valid and binding one between master and trade union, and which then proceeds to find that each employee in the unit, member of the union or not, is contemplated by its terms and intended to be benefited thereby.' The servant may, therefore, enforce the terms of the collective agreement against his master, but the converse, enforcement by the employer against his employee, does not follow. A second rationale relied on by the American courts extends the common law concept of general custom or usage to the collective agreement which upon publication and for the particular unit concerned is transformed into the rule of the industry. It is with reference to that rule or established method of dealing at a given place and in a particular industry that contracts of employment are formed between master and servant." Thirdly, and most directly of all, the trade union is considered to negotiate and execute a collective agreement as

- B.A. (Toronto), LL.B. (Ottawa), LL.M. (Yale). The views expressed herein are my own and in no way represent those of the Canadian Department of Justice, with which I am presently employed.

1 MacKay v. Loeus 182 F. (2d) 170, cert. denied 340 U.S. 828; Yazoo \& M.V. Rwy. Co. v. Sideboard, 161 Miss. 4. 133 So. 669; Piercey v. Louisville \& $N$. Rwy. Co., 198 Ky. 477. 248 S.W. 1042: Gulla v. Barton, 164 App. Div. 293, 149 N.Y.S. 952; Rotnofsky v. Capitol Distributors Corp., 262 App. Div. 521, 30 N.Y.S. 2d 563; Rentschier v. Missouri Pacific Rtwy. Co., 126 Neb. 493, 253 N.W. 694; Marranzano v. Riggs National Bank of Washington, 184 F. (2d) 349 .

2 Aulich v. Craigmyle, $248 \mathrm{Ky} .676,59 \mathrm{~S} . \mathrm{W}$. (2d) 560 ; Hudson v. Cincinatti, N.O. Rwy. Co., $152 \mathrm{Ky}$. 711. 154 S.W. 47; Yazoo \& M.V. Rwy. Co. v. Webb, 64 F. (2d) 902; Rentschler v. Missouri Pacific Rwy. Co., 126 Neb. 493, 253 N.W. 694; U.S. Daily Pub. Corp. p. Nichols, 32 F. (2d) 834 . 
agent of the employees in the unit thereby bringing the latter under this agreement and into direct legal relationship with their employer. ${ }^{3}$ Lastly, the difficulties encountered in the direct enforcement of the collective agreement are avoided by some courts which simply incorporate its terms into the individual hiring contract between an employer and his employee. An action by the latter against his master is then founded on this contract.*

However, when the converse situation arises for consideration and a master wishes to enforce against an employee some term of the collective agreement, the court may find that its former choice of rationale from those set out above will now hamstring its course of action. In Whiting Milk Companies v. Grondin, the defendant was a milkman who belonged to the union that had negotiated the collective agreement with the plaintiff and in issue was a restraint of trade provision in the agreement which purported to bind the employees. The Court merely stated that "the agreement was binding upon Grondin who worked under it as a member of the union". ${ }^{\circ}$ No other basis was given and subsequent cases which have applied its result were equally mysterious in their reasons for judgment. ${ }^{7}$ And yet, if that fundamental concept of law which requires justice to be meted out in accordance with some general principle is to be retained, we should seek a sounder basis for the enforcement by either party of the terms of a collective agreement.

With this brief background of the American experience in mind, we can now proceed to investigate the Canadian attitude towards the enforceability by master and servant of the terms of the collective agreement. Before the intervention of the legislatures, Canadian courts believed themselves confronted with the attempt of a worker to enforce an agreement entered into, not by that individual, but by an illegal association, viz., the trade union. One of the parties to the agreement was considered as being a conspiracy in restraint of trade and outside the law, and therefore the contract itself was deemed unenforceable. ${ }^{\mathrm{g}}$ In Young v. Canadian Northern Railway Co., ${ }^{9}$ a discharged employee sued his former employer on the agreement which only the defendant and the plaintiffs trade union had executed. The Privy Council viewed the case as one which attempted to incorporate the terms of that agreement into the employee's contract of service. Nothing depended on union membership, because the union had contracted on behalf of all employees in the unit.. ${ }^{10}$ However, the Privy Council refused to enforce the provisions of this agreement on the grounds that they were not "adapted for conversion into or incorporation with a service agreement,

3 Mueller v. Chicago \& N.W. Rwy. Co., 194 Minn. 83, 259 N.W. 798; but cf. Piercey p. Louisville \& N. Rwy Co., ante; Hudson v. Cincinatii, N.O. Rwy. Co., ante; Rotnofsky v. Capitol Distributors Corp., ante.

4 Mackay v. Loews, ante, n. 1. Rentschler v. Missouri Pacific Rwy. Co., ante, n. 1.

6282 Mass. 41,184 N.E. 379.

a 282 Mass, 44 ; 184 N.F. 379

7 Western-United Dairy Co. v. Nash, 293 Ill. App. 162, 12 N.E. (2d) 47 ; Schumacher v. Loxterman, 77 N.E. (2d) 257; Western Maryland Dairy Co. v. Chenowith, 180 Md. 236, 23 A. (2d) 660 .

8 Russell v. Amalgamated Society of Carpenters and Joiners, [1912] A.C. 421; Polakoff v. Winters Garments Co., 62 O.L.R. 40.

9 [1931] A.C. 83.

10 Their Lordships anticipated the later legislation that based representation in the collective bargaining prociss on the unit rather than on union membership. Le Syndicat Catholigue des Emrloyes de Magasin de Quebec Inc. v. La Compagnie Paquet Ltee. [1959] S.C.R. 206, 212-213. 
so as to entitle master and servant to enforce inter se the terms thereof"; ${ }^{11}$ and that such an agreement was of a nature to be enforced, not in a court of law, but by strike or other economic action. ${ }^{12}$

These two reasons advanced by the Privy Council raise the issues of whether the terms of a collective agreement can ever be converted or incorporated into a service contract and whether the collective agreement is itself ever to be enforceable by the courts. Both are directed at this one vital point: do the provisions of such an agreement form the subject-matter of a suit which a court will entertain, or must the parties seek their remedies elsewhere?

The American position discussed above emphasizes the technique still followed which attempts to find a rational legal basis for enforcing the terms of this agreement. The various pigeon-holes within the traditions of the common law recognized by the more liberal American courts identify those that might find place in Canada. The theory of the third party beneficiary affords an excellent source for giving relief to an employee, but in the absence of its providing a basis for reciprocal relief to an employer against his employee, a grave practical hurdle is placed in the way of its acceptability. Moreover, judicial authority in Anglo-Canadian jurisprudence is still hostile to the ius quaesitum tertio rule and the few lingering hopes for its adoption have been dashed badly of late. ${ }^{13}$ Labour law has been granted no special dispensation here. ${ }^{14}$

The usage theory would have the terms of a collective agreement constitute the rule of the industry and then as part of the service contract both employer and employee would thereupon be able to enforce these terms. And yet, such a result must ignore the narrow confines to which this doctrine in the past has been restricted. In Devonald v. Rosser, ${ }^{15}$ in finding against a defence pleaded by the master who claimed a general usage in the South Wales tinplate trade that permitted factories to shut down without notice to their workers, Lord Alverstone, C. J. quoted the judgment of an earlier case: ${ }^{16}$

... a custom so universal that no workman could be supposed to have entered upon this service without looking to it as part of the contract. ${ }^{17}$

To be a general usage, it must be notorious at the place at which it applies and be readily ascertainable by the contracting parties: ${ }^{18}$

It is in fact to be regarded as though it were a term so well known in connection with the particular transaction that it was nothing but waste of time to introduce it into the contract.19

The evident difficulties in applying this doctrine to the present labourmanagement context become insurmountable when one realizes that relatively short-term collective agreements and rapidly changing industrial

\footnotetext{
11 Ante, n. 9, at 89.

12 Ibid.

13 Midland Silicones Ltd. v. Scruttons Ltd., [1962] A.C. 446.

14 Holland v. London Society of Compositors, 40 T.L.R. 440; Bryson v. Glenlawn School District, [ig44] 3 D.L.R. 636, 640-1.

15 [1906] 2 K.B. 728.

$1 B$ R. v. Stoke-upon-Trent, 5 Q.B. 303, 307.

17 Ante, n. 15, at 741. [1931] 1 Ch. 310.

19 Per Lord Buckmaster, L. C., in Strathlorne S.S. Co. Ltd. v. Hugh Baird \& Sons Ltd., 1916 S.C. 134, 136, being part of the statement of law adopted by Singleton, J., in Marshali v. English Electric Co. Ltd., 61 T.L.R. 186, 187.
} 
conditions cannot accommodate themselves to this long-term and static requirement. Thus, it is not surprising that the Manitoba King's Bench ${ }^{20}$ and Court of Appeal ${ }^{21}$ in the Young case disposed of this argument rather curtly. Three judges of the latter tribunal replied to it as follows:

There is nothing in the evidence to show that the plaintiff agreed to work under the conditions fixed by the rules. When his contract of employment was made he did not know of their existence. At what time then can it be said that the rules became part of his contract? Wage agreements were made from time to time between Division No. 4 and the defendant. Which particular agreement governed plaintiff's contract? Can it be said that every time a new wage agreement was made its rules automatically attached to his contract? All these considerations show how impossible it is, in the absence of evidence of some active assent on plaintiff's part, to spell out for him a contract incorporating any of these rules.22

Then again, the courts may indeed incorporate the terms of a collective agreement into an enforceable hiring contract between employer and employee. This theory does find support in Canada. In Nelsons Laundries Ltd. v. Manning, ${ }^{23}$ the employer sought to enjoin his former employee, a union member, from breaching a restraint of trade covenant in the collective agreement, which bound "the Union and each employee". In spite of the result of the Young decision and the two hurdles its reasons posed, Dryer, J. enforced the clause as a term included by implication in the contract of service the only provisions of which were those to be found in the collective agreement. These provisions, "which deal with the rights and obligations which are to subsist between the employer on the one part and the employee on the other","4 were the only discernible substance of the service contract between the parties, and as collective bargaining only abrogated the freedom of master and servant to negotiate their own individual terms and not the concept of the service contract itself, the content of that contract had to be discovered somewhere. The place to which the courts have had resort is the collective agreement. ${ }^{25}$ A strange case that apparently applied this notion arose out of an application for an order of certiorari which having regard to the compulsory arbitration provisions in the provincial labour relations statute questioned the jurisdiction of the Ontario Division Court to adjudicate upon an employee's claim for vacation pay. The then Chief Justice of the High Court held that this statutory aspect and the provisions of the collective agreement did not destroy the common law service contract that incorporated into it the terms of employment in the collective agreement and that this contract was still actionable in the courts. The application was therefore dismissed. ${ }^{30}$

Earlier cases, on the other hand, either had looked with disfavour

20 [1929] 4 D.L.R. 452.

21 [1930] 3 D.L.R. 352.

22 Id., at 356.

2351 W.W.R. (NS) 493; 51 D.L.R. (2d) 537.

24 Id., at 499 (W.W.R.), 544 (D.L.R.).

25 See Le Syndicat case, ante, n. 10, at 212.

26 Re Grottoli and Lock \& Son Ltd., [1963] 2 O.R. 254. See also Hamilton Street Railway Company v. Northcott, 58 D.L.R. (2d) 708, where the employer's appeal to the Supreme Court of Canada against the award of the guaranteed minimum wage under a collective agreement that also set forth machinery for the arbitration of disputes was dismissed. Both it and Shank v. The K.V.P. Co., [1966] 2 O.R. 847, 860, in their interpretations of the Grottoli decision and in their own reasons confine the employee's success in Northcott and Grottoli to where the decisive term in the hiring contract was not reproduced in the collective agreement. See post, at 15-18. 
upon such a device, ${ }^{27}$ or had regarded the collective agreement as itself the only possibly enforceable instrument. ${ }^{28}$ But whereas these recent Canadian cases incorporated the terms of the collective agreement into the service contract by implication, this same process has also been accomplished by express language ${ }^{20}$ and by statutory command. ${ }^{30}$ In fact, the case just cited appears to reason that as a collective agreement remains unenforceable at common law, consequently, some means must be found for transforming it into something upon which the law may act. The means there found was the Contracts of Employment Act ${ }^{31}$ which provides for written notice of where the terms of employment may be discovered to be served on an employee. This the employer followed, the notice referring to the collective agreement and as a result

these working rules are not only a collective agreement between the union and the employers. They are incorporated into the contract of employment of each man, insofar as they are applicable to his situation. ${ }^{32}$

In similar fashion, Canadian cases have searched for some catalyst by which the terms of a collective agreement might be carried over into a service contract and hence into something with which the courts are familiar. It is reasoned that the parties to a new contract of employment must necessarily have contemplated the terms of this collective agreement as part of their arrangement. ${ }^{33}$ However, so long as the individual service contract is to remain a reality, ${ }^{34}$ one cannot overlook that though the workers in the unit and their service contracts remain unchanged, the terms of the collective agreement will be far less static. ${ }^{33}$ The terms implied by the courts must be wide enough to incorporate both the provisions of the collective agreement then in force and of those subsequently executed, so that a worker's contract of employment will reflect at any given time the substance of the collective agreement at present governing the parties "insofar as they are applicable to his situation".

The last of the American rationales and the second question posed by the Young decision ${ }^{36}$ raises the recurring problem of the enforceability of the collective agreement by the courts, but this time in a modern setting which gives statutory recognition to the processes of collective bargaining and to its ultimate offspring, the collective agree-

27 Young v. Canadian Northern Railway Co., [1930] 3 D.L.R. 352, 356; Murphy v. Robertson, [1938] 1 D.L.R. 369, appealed to Supreme Court of Canada on a procedural point only, [1939] S.C.R. 273; Bancroft v. C.P.R., 53 D.L.R. 272; cf. Caven v. C.P.R., [1925] 3 D.L.R. 841, 841-2 (P.C.) and Ziger v. Shiffer and Hillman Co. Ltd., [1933] O.R. 407.

28 Aris v. Toronto, Hamilton \& Buffalo Rwy. Co., [1933] O.R. 142, 146; Wright v. Calgary Herald, [1938] 1 D.L.R. 111 .

20 National Coal Board v. Gallery, [1958] 1 W.L.R. 16.

30 Camden Exhibition v. Lynott, [1965] 3 All E.R. 28.

311963 Statutes, c. 49.

32 Id., at 31, per Denning, M.R.

33 In Nelsons Laundries Ltd. v. Manning, ante, n. 23, the learned judge quotes from Scammel \& Nephew Ltd. v. Ouston, [1941] A.C. 251, 268: "The object of the Court is to do justice between the parties and the Court will do it best if satisfied that there was an ascertainable and determinable intention to contract, to give effect to that intention, looking at substance and not mere form", per Lord Wright.

34 And authority certainly gives support to this. In Le Syndicat, ante, $n .10$, at 212-3 it was stated:

"The collective agreement tells the employer on what terms he must in the future conduct his master and servant relations. When this collective agreement was made, it then became the duty of the employer to modify his contracts of employment in accordance with its terms so far as the inclusion of those terms is auployment in accordance with its term

This is applied in the Grottoli decision, ante, $n$. 26, and forms the basis of the decision in Nelsons Laundries, ante, n. 23. See also J. I. Case Co. v. N.L.R.B., 321 U.S. 332.

30 Ante, n. 9. 
ment. To grant it the same pride of place and presence before the courts as is given to any ordinary contract would obviate the judicial acrobatics discussed above and would permit employer and employee to enforce it directly against the other. But the first obstacle always raised here wonders how an employee can be bound by this contract which only his employer and union have executed. The trade union might be considered agent of the employees, but even where applied in the United States ${ }^{37}$ it has been recognized as a fiction preferably to be cast aside in favour of more realistic foundations. It seems disingenuous to regard the union as agent of the employee of the unit when the presumed principal immediately after appointing this "agent" should possess so little control over negotiations and, therefore, over the ultimate terms of the collective agreement. The contractual relationship that governs membership in a trade union ${ }^{38}$ may well impose certain responsibilities on the association in favour of its members which are akin to those of an agent, such as ratification by the membership of any collective agreement negotiated by it, but this will be of little comfort to employees in the unit who are not members of the trade union. Then again, it is difficult to harmonize this argument of agency with the presence of dissenters in the unit from the negotiated contract and yet it is the individual worker who as our concern must therefore be the consenting principal under this theory. Any purely common law explanation of this approach seems so fraught with difficulties that little reliance, in fact, has been placed upon it.

But statutes now have been universally enacted in Canada to channel labour-management relations into paths which the legislatures believe to be more in conformity with the public interest. So, in British Columbia where the Labour Relations Act binds the employer, trade union, and employees of the unit as parties to a collective agreement, ${ }^{30}$ Nelsons Laundries, in an obiter dictum, stated that this provision had the effect of establishing an agency relationship between employee and trade union, while exclaiming that this "also exists quite independently of specific legislative provisions". ${ }^{40}$ However, a more authoritative pronouncement on this subject has been uttered by the Supreme Court of Canada which was considering the 1941 Quebec Labour Relations Act: ${ }^{41}$

There is only a legislative recognition and certification of a union as the collective representative of the employees, provided the union comprises the $a b-$ solute majority of the employees. When this situation arises the employer must negotiate and contract with the collective representative and the collective representative represents all employees, whether union. members or not, not because of a contractual relation of mandate between employees and union but because of a status conferred upon the union by the legislation.

If the relation between employee and union were that of mandator and mandatary, the result would be that a collective agreement would be the equivalent of a bundle of individual contracts between employer and employee negotiated by the union as agent for the employees. This seems to me to be a complete misapprehension of the nature of the juridical relation involved in the collective

37 See ante.

38 Orchard v.Tunney, [1957] S.C.R. 436.

39 R.S.B.C. 1960 , c. 205 , s. 20.

10 Ante, n. 23, at 498 (W.W.R.), 543 (D.L.R.).

41 R.S.Q. 1941, c. 162A, as amended, ss. 4 and 9, now the Quebec Labour Code, R.S.Q. 1964, c. 141 . 
agreement. The union contracts not as agent or mandatary but as an independent contracting party and the contract it makes with the employer binds the employer to regulate his master and servant relations according to the agreed terms. 42

Thus, the realities of the situation condemned this theory of agency as inappropriate.

One may ask then for what purposes a collective agreement is binding upon its various parties and whether the statute that produces this effect also confines it to the remedies and legal relationships expressed in the enactment itself. Such a limiting consequence may seem to complement the position set forth in the Young case that, in the absence of statutory alteration of the common law position, the only means of enforcing a collective agreement lies with the strike and other economic weapons. Nevertheless, as later cases make clear, statutes have indeed revolutionized the law of industrial relations. No longer is an unregistered trade union $^{43}$ an illegal association incapable of being recognized by the courts as party to an action: quite apart from those statutory provisions giving legal standing to a trade union for purposes of the Act alone, the Canadian courts have now appreciated that the law, in clothing this body with certain obligations, duties, rights, privileges, etc., has acknowledge them sufficiently that they may now be considered to possess full status as legal entities.4 But not only is the trade union no longer an illegal association, but the collective agreement too has received a legal standing. A great many provisions of the various statutes in this area are concerned with the collective agreement: the parties, how it is to be negotiated, its form and content, its consequences and enforcement. Thus whereas in the past the courts would not enforce this agreement because either it was believed the parties so intended ${ }^{45}$ or one of the parties remained an illegal entity which tainted the entire transaction, ${ }^{16}$ the statutes now effect a radically contrary result in which the collective agreement is considered to be the very cornerstone of labour-management relations. So it has been said:

That (the situation at the time of the Young decision) is not the case to-day. Since the enactment of legislation providing machinery for negotiation and filing of collective agreements, and penalties for failure to observe them, and the development of industrial relations practices thereunder, collective agreements have become and are accepted as agreements which do create obligations enforceable at law.4

For that statement, Dryer, J. referred back to a case ${ }^{48}$ where the Court, on the basis of correspondence between the parties, had made a declaration of the terms of the collective agreement and ordered the defendant

42 Le Syndicat case, ante, n. 10, at 214.

43 Cf. Trade Union Act, R.S.C. 1952, c. 267 for the position of a registered trade union and the consequences of this in Taff Vale Railway Co. V. Amalgamated Society of Railway Servants, [1901] A.C. 426.

14 International Brotherhood of Teamsters v. Therien, [1960] S.C.R. 265; Nipissing Hotel Ltd. v. Hotel \& Restaurant Employees and Bartenders Association, [1963] 2 O.R. 169; Contractors Equipment and Supply (1965) Ltd. v. Building Material Drivers, etc. Local 914,53 W.W.R. (NS) 702; Senkiw v. Utility Grove (1961) Ltd., 58 D.I.R. (2d) 754 .

45 Young case, ante, n. 9, at 89.

46 See ante, n. 8.

4 Ante, n. 23, at 497 (W.W.R.), 542 (D.L.R.)

18 Hume \& Rumble Ltd. v. Local 213 of International Brotherhood of Electrical Workers, [1954] 3 D.L.R. 805. 
to execute it. But the courts have also adjudicated upon the agreement itself by way of declarations, injunctions and damages. ${ }^{.0}$

\section{II}

A very basic argument the courts must face in these cases is founded on the legislative supremacy of Parliament and its constitutional power to oust the jurisdiction of the courts from any matter it so wishes. While this result may only be obtained by means of clear statutory language that expressly or by necessary implication removes jurisdiction from the courts over a particular res, it is usual to find that the obliteration of an otherwise valid judicial remedy is accompanied by the establishment of new agencies and forms for giving relief in the self same circumstances. It may be found that the subject in issue has been assigned to a different or newly constituted court or administrative tribunal and thus by either the express words or necessary intendment of the legislative language, redress must be sought exclusively from this body. As might be expected here, and warmly welcomed too, the courts remain jealously vigilant of jurisdiction so hard won over the years and very reluctantly will they surrender any of it to some other authority. In the words of Milvain, J.

I am further of the view that Courts must be ever mindful of their responsibility to society in seeing that their jurisdiction is preserved and protected against surrender to administrative tribunals. ${ }^{.0}$

This battle to retain and also to usurp justiciable matter is no recent phenomenon and one need only cast a glance back into English legal history to be reminded of the struggles then carried on amongst the different courts to obtain jurisdiction-and fees-from each other. At that time, a favourite device of the judges was the legal fiction, but at present our own firmly entrenched courts look only to the manifestations of legislative intent, namely, statutes and subordinate legislation, for the sources of any curtailment of their powers.

The crux of the matter is reduced, therefore, to the issue of statutory interpretation and whether the language of the legislature has ousted the court's jurisdiction. ${ }^{51}$ Less difficulty arises in situations where the statute creates both a new right and the remedy to give effect to it; then, with none of their present powers threatened the courts feel less uneasy and subject to attack by administrative tribunals. ${ }^{52}$ On the other hand, where the courts already entertain authority over a certain matter and legislation then seeks to transfer it to another body, a more recalcitrant position is taken and the courts become much less inclined to surrender anything to this non-judicial agency. ${ }^{53}$ So, one finds that child

40 Wheaton v. Local 1598, Carpenters' Brotherhood, 6 D.L.R. (2d) 500; Doman's Transport Ltd. v. Building Materials, etc. Union, 40 D.L.R. (2d) 492; Kelly, Douglas \& Co. Ltd. v. Bakery \& Confectionery Workers, 48 D.L.R. (2d) 520; Gulf Islands Navigation Ltd. v. Bakery \& Confectionery Workers, 48 D.L.R. (2d) 520; Gulf Islands Navigation
Ltd. v. S.I.U., 18 D.L.R. (2d) 216, affirmed at 625; Winnipeg Builders Exchange v. Ltd. v. S.I.U., 18 D.L.R. (2d) 216, afflrmed at 625; Winnipeg Builders Exchangev.
Operative Plasterers, 48 D.L.R. (2d) 173; Winnipeg Builders Exchange v. I.B.E.W., 57 D.L.R. (2d) 141 .

50 Calgary \& Edmonton Corp. Ltd. v. B.A. Oil Co. Ltd., 40 D.L.R. (2d) $964,971$.

51 See generally Wolverhampton New Waterworks Co. v. Hawkesford (1859), 6 C.B.N.S 336, per Willes, J.; Ganz, The Limits of Judicial Control Over the Exercise of Discretion, [1964] Püblic Law 367; Zamir, The Declaratory Judgment.

52 Barraclough v. Brown, [1897] A.C. 615; Wilkinson v. Barking Corporation, [1948] 1 K.B. 721.

53 See Pyx Granite Co. Ltd. v. Ministry of Housing and Local Government, [1960] A.C. 260; Francis v. Yiewsley and West Drayton U.D.C., [1957] 2 Q.B. 136, 148; Baron v. Sunderland Corp., [1966] 1 All E.R. 349 
welfare legislation has been held not to oust the jurisdiction of the courts to hear a custody application ${ }^{54}$ and that grievance procedures established by subordinate legislation to govern the civil service did not deprive an employee of his claim to damages before the courts. ${ }^{35}$ Nevertheless, grievance disputes over the provisions of hiring contracts may have been removed entirely from the judiciary and placed in the hands of an administrative body. ${ }^{30}$

Although the words of the enactment in question provide the primary solvent for this problem of whether the court has or has not been deprived of its jurisdiction, a purely literal approach may well ignore the practical context in which the statute was intended to operate and the administrative distortions that might thereby be occasioned in the face of what the legislation set out to accomplish. Administrative law has grown by means of gradual incursions of government into areas formerly subject to the scant controls of the market-place and a laissez-faire philosophy. The State has not only become more aware of the economic and social evils that beset a system governed by laws rooted in these purely self-serving principles, but has found that the introduction of greater measures of protection and equity into society also requires its direct participation. Administration of the programmes and policies thereby enacted into law is placed in the hands of tribunals which, like judges, are appointed by the executive arm of the government, but the tenure of which is generally far less secure and whose powers in their own particular field of action may be of far wider scope than those of the judiciary. The administration of laws entrusted to these tribunals, moreover, is intended to differ in quality from the functions of the judiciary. The underlying object of creating these bodies rests on the need to fill in the interstices purposefully created by a legislature that must try to meet endless and manifold situations which can be neither foreseen nor forecast accurately by the statute in order to carry out the inherent policies of the scheme. Within its perimeters, wide and shadowy though they will often be, the administrative tribunal is authorized to make its decisions and often even to establish policies; legislative, judicial and administrative functions become intermingled and the tribunal may find that the courts too are being asked to rule upon some question arising from this same piece of legislation.

It is in this administrative arena that the prerogative writs and their successors have enjoyed their greatest victories, but these remedies and the increasingly popular declaration and injunction are not granted for purposes of disputing the merits of a decision upon the facts. They are generally concerned only with the jurisdiction, procedure and patent errors of law of the tribunal, but in the very act of confining them within these limits the courts are acknowledging the administrative process and those many responsibilities and functions which are inherent in it. The courts admit to having no concern with the policies of the statute: rather, they concentrate their attention upon the manner in

54 Dube v. Minister of Social Welfare and Rehabilitation, 42 W.W.R. (NS) 86.

55 Washer v. B.C. Toll Highways and Bridge Authority, 53 W.W.R. (NS) 225, 228.

50 In re Birkenhead Corp., [1952] Ch. 359. See also Healey v. Minister of Health, [1955] 1 Q.B. 221, and Wilkinson v. Barking Corporation, ante, n. 52. 
which that policy is carried out. ${ }^{57}$ And yet one characteristic task of these bodies has them reaching decisions in a manner very similar to that found in a court of law. Why legislatures have felt increasingly disinclined to rely upon the services of the judiciary in the very realm where they claim a tradition of mastery finds substance in the conflict between their procedures laying heavy emphasis on high standards of justice and society's now greater concern for the public interest. The very merits of a court, the impartiality of the amateur with no vested interests, its elaborate and careful machinery, its ponderous search for the truth, all brought to bear to protect the litigant, are the characteristics that make it unsuitable to carry out a legislative policy which requires day-to-day forms of administration. What are thought desirable in this process of administrative decision-making are speed, expertise and efficiency.

If the public interest demands a certain scheme or policy, then in consequence it must also accompany that scheme with suitable means of carrying it through in accordance with that public interest. But what is the public interest? One must seek to discover this in the legislative policy laid down in the statute. The knowledge of, and familiarity with, these goals on the part of the administrators of the statute increase the likelihood that their actions will accord with what the legislature intended. This expertise and vested interest in the scheme are at variance with the familiar diffidence of the courts, but it remains still the most suitable method for giving flesh and blood to the legislature's skeleton. Yet it cannot be gainsaid that actions taken in the name of the public interest may at times not only overlook, but blatantly ignore, the rights of the individual. Hence, arises the constant search for a proper balance between these two competing values. ${ }^{58}$

Either of two extreme positions might be adopted in order to determine where the balance lies. To favour private rights only would have us return to unhappy eras from which we are still struggling to escape, whereas reliance only on the public good, the definition of which is to be left in the hands of the State and its appointed officials, must lead inevitably to some form of dictatorship. Between these two we carry on the search for proper and workable accommodation. Not only must the piece of legislation in issue be made to function satisfactorily, but an insight into how this is to be accomplished can only be gained by considering the over-all purposes sought to be attained and the laws already operating in this theatre of activity. The social underpinnings of the legislation, a result of the sociological, economic, psychological and other interests which gave birth to the scheme, can only be ignored in its ultimate interpretation and application at the cost of emasculating what was thereby hoped to be achieved. On the other hand, the legislature could not have intended an enactment which took no notice of other laws and forms of solution already operating in the area of concern. A

57 H.W.R. Wade, Law, Opinion and Administration, 78 L.Q.R. 188; Lord Devlin, Public Policy and the Executive, [1956] Current Legal Problems 1, at 8; E.C.S. Wade. The Courts and the Administrative Process, 63 L.Q.R. 164.

58 E.g. Griffith and Street. Principles of Administrative Law (3d ed.) at 148-156; Wade, Administrative Law, at 196-7; Lord Denning, Freedom under the Law, at 69-77: Report of the Committee on Administrative Tribunals and Enquiries (Franks' Report). Cmnd. 218, at 9, 58-61; Robson, Justice and Administrative Law (2d ed.): Jaffe, Primary Jurisdiction, 77 Harv. L.R. 1037, at 1037-48; Carr. The Non-Judicial Judge, 65 L.Q.R. 188. 
functional interpretation of enactments which create an administrative competence attempts to account for all these relevant factors ${ }^{50}$ and in so doing tries to determine how each may be most usefully applied while merging them all into a harmonious whole.

With this before us we perhaps can make a more worthwhile attack upon the issue now at hand, namely, the statutory ouster of the jurisdiction of the courts. Statutes governing labour-management relations in Canada generally provide that the parties to a collective agreement settle their disputes by "arbitration or otherwise"." However, Quebec Ontario and Saskatchewan restrict their method for settling grievances to arbitration, ${ }^{61}$ and three ${ }^{02}$ of the other provinces, where provisions for dealing with these disputes are omitted from the collective agreement, require the parties to submit to an arbitral clause.

A number of cases have arisen recently in Ontario in which an employee has tried to enforce the terms of a collective agreement in a court of law. In Re Grottoli and Lock \& Son Ltd., ${ }^{\text {"3 }}$ a Division Court suit had been commenced to collect vacation pay and the employee claimed that under his collective agreement he was entitled to a sum based on $4 \%$, whereas in fact he had received only $2 \%$. An application for certiorari was taken to the High Court on the ground that the Division Court was without jurisdiction and the plaintiff could claim relief only through the arbitral processes in the agreement. The action was sustained, however, under the contract of employment: the common law relationship of master and servant remained and

If the employer fails to pay promptly the employee in my mind clearly has a right of action against his employer to claim the wages due to him..$^{64}$

However in Shank v. The K.V.P. Company, ${ }^{65}$ the dispute concerned the company's right to schedule employees, a matter that fell to be decided in accordance with the terms of the collective agreement, and Brooke, $\mathrm{J}$. held that this motion for an injunction failed for want of the Court's jurisdiction. No action on the agreement would lie at common law and section 34 of the Labour Relations Act of Ontario required the issues arising out of that agreement to "be dealt with by arbitration and are not within the jurisdiction of this Court to determine". ${ }^{66} R e$ Grottoli was distinguished on the ground that it involved a simple claim for wages which was not a matter that the employee was required to process through arbitration. Yet, the action for vacation pay in that case rested quite obviously on the provisions of the collective agreement and McRuer, C. J. H. C. attempted to circumvent the conclusion reached in Shank by resorting to the rationale based on the employment contract. ${ }^{67}$ In doing so, he, in effect, was admitting that the collective agreement itself was

\footnotetext{
60 Jaffe, Primary Jurisdiction, ante, n. 58; Griffith and Street, Principles of Administrative Law, ante, n. 58.

oo Canada: R.S.C. 1952, c. 152, s. 19; Newfoundland: R.S.N. 1952, c. 258, as amended in 1960 , c. 58 , s. 19 ; Prince Edward Island: S.P.I.I. 1962, c. 18, S. 23; Nova Scotia: R.S.N.S. 1954, c. 295, s. 19; New Brunswick: R.S.N.B. 1952, c. 124, s. 18; Manitoba: R.S.M 1954, c. 132, s. 34; Alberta: R.S.A 1955, c 167, as amended in 1964, c. 41, s. 73; British Columbia: R.S.B.C. 1960, c. 205 , s. 22.

61 Quebec: R.S.Q. 1964, c. 141, s. 88; Ontario: R.S.O. 1960, c. 202, s. 34; Saskatchewan: R.S.S. 1965, c. 287 , as amended in 1966 , c. 83 , ss $23,23 \mathrm{~A}$ and $23 \mathrm{~B}$.

62 Newfoundland, Manitoba and Alberta.

63 Ante, n. 26.

64 Id., at 256.

65 [1966] 2 O.R. 847.

06 Id., at 861 .

o7 Ante.
} 
not enforceable in the courts, but simultaneously failed to avoid encouraging reliance on a theory which could not help but destroy the entire statutory structure for the settlement of grievances under collective agreements. ${ }^{68}$

In Hamilton Street Railway Co. v. Northcott, ${ }^{19}$ the Supreme Court of Canada heard an appeal from a judgment which had awarded the plaintiff, a former employee of the appellant, a sum of money that represented the minimum wage owing to him under a collective agreement. A Board of Arbitration had upheld the grievance filed by the union, but on the request of counsel for the trade union had made no specific award. Consequently, the courts were called upon by this individual employee to specify the exact sum of money owing to him as a result of the declaration of the arbitral tribunal that all the employees were entitled to the minimum wages in issue. The Supreme Court relied on the Grottoli decision in holding that the employees can ask the courts to fill in an arbitral declaration that a worker has the right to a certain class of wages by means of a judgment for the specific sum which this right in fact represents. The fear was expressed that if an employee failed to follow the precise procedural requirements of the collective agreement, he might be left without any wages at all though admittedly they were owing.

The collective agreement is not concerned with non-payment of wages. These may be sued for in the ordinary Courts. If, however, the right to be paid depends upon the interpretation of the collective agreement, this is within the exclusive jurisdiction of a board of arbitration appointed under the agreement. . . $: 0$

In the last Ontario case, Close v. The Globe and Mail, ${ }^{, 1}$ vacation pay again was in dispute, but the Court of Appeal denied that the courts had any power to adjudicate upon the matter. In reference to the Grottoli case, the Court stated that there only the amount of, and not the right to, vacation pay was in issue, whereas here the substance of the dispute centred upon whether the plaintiff was entitled to vacation pay at all. Of the two earlier case, Grottoli and Northcott:

It is to be noted that in neither of these cases did the defendant bring into issue the right of the plaintiff, in some forum, to obtain the relief sought; what was in issue was whether an employee being a member of a bargaining umit as agent for which a union had entered into a collective bargaining agreement with the employer, hat the right of recourse to the courts for the enforcement of the payment to him of wages which the employer improperly withheld, while admitting them to be due and owing. The foregoing cases have established beyond question that in such circumstances the jurisdiction of the courts is unaffected by the provisions of a collective bargaining agreement, the Labour Relations Act and the Rights of Labour Act.'2

Later in the judgment it was made clear that the Court relied primarily upon the Labour Relations Act and its provisions which imported into the collective agreement the grievance procedures that had to be resorted to by the parties.

And so we find a specious distinction to have grown up in the cases between claims for wages where only the sum is in issue and actions to adjudicate upon the specific rights and obligations in the collective agree-

\footnotetext{
68 See Rideout. The Contract of Employment, [1966] Current Legal Problems 111, where the inapplicability of contract law to modern employment situations is discussed. 6058 D.L.R. (2d) 708 .

6058 D.L.R.

71 66 C.L.L.C. 11, 707: [1967] 1 O.R. 235.

72 Id., at 709 (C.L.L.C.); 239 (O.R.).
} 
ment. The nearest the courts approach a rationale for this dichotomy is found in their recognition that the collective agreement in these cases has not encompassed completely all the terms of employment governing the workers in the unit. The residuum must be discovered in the particular contract of employment of each employee and thus the language of the Syndicat case $^{i 3}$ must be interpreted in this light in order to acknowledge that the individual hiring contracts may indeed contain terms which, because outside the collective agreement, are not subjected to the provisions of the Labour Relations Act and the Rights of Labour Act. ${ }^{i 4}$ The singular paradox apparent in this inapt distinction between the right to wages and the actual sum to which this right appertains is that the court has forced itself into the position where an arbitral tribunal is held capable of declaring legal relationships, i.e., whether an employee has a right to wages as against his employer, and the court then merely acts as master upon a reference to determine the exact sum owing. This assuredly evidences an ironic reversal of roles. The Court in the Northcott decision expressed concern for an employee's inability to be able to collect his wages should he fail to follow precisely the grievance machinery provided. Yet, this in itself admits that a formula for settling these disputes has been specially set out in the agreement. However the Court never proceeds then to recognize not only that this particular procedure was negotiated freely by employer and trade union as part of the collective bargaining process, but that in the forceful legislative language sanctioning this procedure the consequent effects of the arbitration clause may well lay stronger claims here to debarring consideration by the courts than in the ordinary case of a purely contractual provision for arbitration which nevertheless still requires an arbitral award as a condition precedent to the intrusion of the courts. ${ }^{i 5}$ On the other hand both Northcott and Shank do establish that once a matter is included as a term of the collective agreement, it falls exclusively within the agreement's grievance procedures and to the Board of Arbitration established thereby. ${ }^{76}$

One cannot depart from the Ontario cases without remarking upon the additional support given here by the Rights of Labour Act. ${ }^{77}$ Section 3 (3) of that statute expressly prohibits the collective agreement from forming the basis of a suit before the courts "unless it may be the subject of such action irrespective of any of the provisions of this Act or the Labour Relations Act". This is relied on in Cummings v. H.E.P.C. of Ontario ${ }^{78}$ for refusing to rule upon the terms of a collective agreement and the Shank case refers to it as an alternative ratio. In Northcott, it is held to be inapplicable because the plaintiff is suing on an arbitral award rather than upon the collective agreement, but in so holding the Court acknowledges its own subordinate position to that of the parties' Board Arbitration. However, as Ontario and Saskatchewan ${ }^{79}$ appear to be the only jurisdictions having such an enactment, it is able to offer little comfort

is Ante, n. 10.

74 See Northcott, ante, n. 69, and Le Syndicat, id., at 212, where it was stated: "Certainly to the extent of the matters covered by the collective agreement, freedom of contract between master and individual servant is abrogated". See also J.I. Case Co. v. N.L.R.B., ante, n. 34 .

is See post.

78 Shank case, ante, n. 65, at 860; Northcott case, ante, n. 69.

i7 R.S.O. 1960, c. 354 .

78 [1966] 1 O.R. 605

79 Trade Unions Act, R.S.S. 1965 , c. 287 as amended, s. 27. 
in any attempt to analyze the situation elsewhere. Moreover, apart from the Cummings case, even the Ontario courts have paid scant regard to this provision.

The other cases have occurred in British Columbia and New Brunswick. Nelsons Laundries Ltd. v. Manning expressly avoided this problem, ${ }^{80}$ but New Brunswick's Appellate Division ${ }^{81}$ had to consider the claim for wrongful dismissal under a collective agreement which provided for the arbitration of grievances. Under the New Brunswick Labour Relations Act," grievance procedures by "arbitration or otherwise" must be inserted in the agreement" and the parties so bound "shall comply with the provision for final settlement contained in the agreement and give effect thereto". ${ }^{84}$ Nevertheless, the employee under the Act and this agreement was not confined to the grievance procedure in order to remedy any complaint he might have, but the Court then proceeded to restrict this conclusion to cases where the grievance procedure had never been pursued to an ultimate arbitral award. The basis for this distinction lies in the law applicable to contractual arbitration clauses which the parties stipulate for themselves and which, though unable to oust the jurisdiction of the courts, may nevertheless require as a condition precedent to recourse to the courts that the parties first submit their dispute to the decision of an arbitrator. The decision will then only be upset by the courts upon very specific and narrow grounds. ${ }^{85}$ Yet one may ask why the courts should treat so lightly the statutory scheme for the settlement of grievances which the parties have inserted in their agreement under legislative command. For to do so ignores the specific enactments which rule industrial relations in such detail and reverts rather to an earlier epoch when no controls and caveat contractor caused that great distress and injustice which finally necessitated legislative action. In these pre-statutory times, Caven v. C.P.R. ${ }^{80}$ which involved a dismissed employee and a grievance procedure that had not been entirely exhausted by him, was indeed founded on the law of arbitration and on the Privy Council's refusal, in accordance with Scott v. Avery, to interfere with the arbitrator's conclusion. But in the presence of the comprehensive labour codes in force to-day, reliance on these common law principles seems misplaced. Not only are grievance procedures compulsory, but the statutes also require the parties to abide by the decision reached. Why then do Woods, where such an enactment governs, and Caven, which had no such legislation, proceed on the same reasoning ${ }^{87}$

What the Court in the Woods case expressed as motivating their decision was the fear that the trade union might not support the grievance of an individual employee in which case the latter's only remedy would lie with the courts. A practical example of this is presented in the Northcott case, but the Court makes no effort to show how the person aggrieved might be able to force arbitration procedures on an unwilling

80 Ante, n. 23, at 499 (W.W.R.) ; 543 D.L.R.

81 Miramichi Hospital v. Woods, 66 C.L.L.C. 11, 702; 59 D.L.R. (2d) 290.

R2 R.S.N.B. 1952 , c. 124 .

83 Id., s. 18 (1).

Bt Id., s. 18 (3).

85 Scott v. Avery, 5 H.L.C. 811. See generally Russell on Arbitration, (17th ed.), at 36-7, ch. 6

8 [1925] 3 D.L.R. 841 (P.C.).

87 See Carrothers, Labour Arbitration in Canada, at 99-102. 
employer and trade union. Yet in accordance with the terms of the agreement, the courts need only enjoin the parties to follow the grievance procedures provided therein; ${ }^{48}$ and to obviate the predicament of the unfortunate Mr. Northcott, the grievor might be made aware that as his rights under the agreement are to be decided entirely by these procedures, he must prepare himself as if for court.

Whether the statutes in truth have ousted the jurisdiction of the courts here finds little guidance in those cases which have raised the issue of the availability of a remedy to parties aggrieved by the arbitral award. That the jurisdictions where arbitration alone is the mode of finally settling grievances, permit that such administrative remedies as the prerogative writs and their successors may be asserted against these statutory boards, ${ }^{{ }^{\circ}}$ contrasts sharply with those where no such remedies may be claimed because the statutory machinery for settling grievances allows for other procedures than arbitration, ${ }^{90}$ only evidences the possibility that statutory ouster may have been accomplished in favour of additional solutions to that of arbitration. Whether the parties to a collective agreement have no alternative but to settle their disputes finally by some form of arbitration, or are at liberty to select some other machinery which they believe more appropriate, in either case that provision has been expressly and absolutely required as a term of the agreement. Not the particular form of grievance machinery, but rather the legislative command that there be an extra-curial manner of settling disputes, raises the issue of statutory ouster with respect to the legislation of every jurisdiction in Canada.

While a legal rationale for the judicial claim to concurrent jurisdiction over the terms of the collective agreement with that of the grievance machinery of the parties may be found in the foregoing, nevertheless the cases themselves do not necessarily support the arrival at such a conclusion. It is appropriate, therefore, to enter upon a discussion of whether the courts should participate in this function.

Confusion and emotions are bound to run high in so highly charged a field as labour law, and where the court's jurisdiction over actions as time-honoured as those arising out of contracts of employment now is being brought into question. For the most part, the cases referred to earlier in the general discussion of ouster of jurisdiction ${ }^{91}$ had been

88 See Textile Workers v. Lincoln Mills, 353 U.S. 448. Although this case relies on section 301 of the United States National Labour Relations Act, 61 U.S. 156, 29 U.S.C. 185, which expressly permits suit to be brought on the collective agreement, that provision has not weakened the resolve of the American courts to require the parties to conform to the arbitration processes which the parties themselves have inserted in their agreement: United Steelworkers of America v. Warrior \& Gulf Navigation Co. 363 U.S. 574; United Steelworkers of America v. Enterprise Wheel and Car Corp., 363 U.S. 593; United Steelworkers of America v. American Manufacturing Co., 363 U.S. 594. $A$ fortiori, in Canada where no equivalent of section 301 exists and where, unlike in the United States, legislation demands grievance machinery as set out in the agreement and statute. If the courts balk because they feel they cannot even consider the collective agreement for purposes of enforcing arbitration, it must be remembered that not only have they adjudicated upon the agreement for the purposes cited above, but they have also had to permit it to be the subjcet-matter of motions to quash above, but they have also had to permit it to be the subjcet-matter of motions to

89 Re International Nickel Co. and Rivando, [1956] O.R. 379, 386; Re Polymer Corp. and Oil, Chemical \& Atomic Workers'Union, [1962] S.C.R. 338, affirming [1961] O.R. 438 176. But cf. Canadian British Aluminium Co. Ltd. v. Dufresne, [1964] C.S. 1, decided under the former Quebec Labour Relations Act now discarded in favour of the new Labour Code, ante, n. 61.

90 Howe Sound Co. v. International Union of Mine, Mill and Smelter Workers, [1962] S.C.R. 318 (B.C.); Re Atlantic Sugar Refineries Ltd. and Bakers' Union, 27 D.L.R. (2d) 310 (N.B.); Re Evaschuk, 44 D.L.R. (2d) 700 (Alta.) 01 Ante. 
concerned with the enforcement of new statutory rights. Some, of course, had to consider actions already known to the law, but the averment in those cases that the court was without jurisdiction usually met with far less success.": Still, the general principle of law that was stated by Willes, J. in Wolverhampton New Waterworks Co. v. Hawkesford ${ }^{93}$ and referred to with approval in the House of Lords ${ }^{94}$ remains with us:

There are three classes of cases in which a liability may be established founded upon a statute. One is, where there was a liability existing at common law and that liability is affirmed by a statute which gives a special and peculiar form of remedy different from the remedy which existed at common law; there, unless the statute contains words which expressly or by necessary implication exclude the common law remedy, and (sic) the party suing has his election to pursue either that or the statutory remedy.

Obviously, therefore, in respect of rights and duties arising out of contracts of employment, the remedies furnished by labour relations statutes will fully displace their common law counterparts only if there exists express or implied statutory language to that effect.

These enactments do contain certain remedies for breaches of the collective agreement, which include criminal prosecutions, proceeding before the Labour Relations Board and the machinery in the agreement for settling grievances between the parties. Only the first of these takes the parties before the courts and even here the prior permission of some administrative or executive personage is generally required. ${ }^{05}$ Thus, the legislative policy, as crystallized in the collective agreement, gives little encouragement to recourse to the courts. The inherently selfcontained machinery controlling industrial relations to be found in these statutes has only recently been expressed forcefully by the courts. In Re Etmanski and Taggart Service Ltd., ${ }^{96}$ the Ontario Court of Appeal was being asked to consider a situation under the federal Industrial Relations and Disputes Investigations Act $^{97}$ in which the respondent had refused to appoint an arbitrator under the parties' collective agreement until certain preliminary steps had been observed by the applicant. The Act specified settlement of disputes by "arbitration or otherwise,"9s but the collective agreement, which had stipulated for a grievance machinery founded on arbitration, had not foreseen the situation where one party refused to appoint his nominee to the Board of Arbitration. The Court considered that under section 19 (2) the Canada Labour Relations Board had the power to remedy this situation and that, consequently, the applicant could not resort to the Ontario Arbitrations Act.

... there is provided within the Act itself provision for the enforcement of provisions of the collective agreement and where this agreement proves deficient in any respect means are provided for its correction. In other words, the Act provides completely for final settlement without stoppage of work of all differences between the parties.99

0. Baron v. Sunderland Corp., ante, n. 53; Dube v. Minister of Social Welfare and Rehabilitation, ante, n. 54; Washer v. B.C. Toll Highways and Bridges Authority, ante, n. 55.

83 Ante, n. 51 , at 356.

04 Pyx Granite Co. Ltd. v. Ministry of Housing and Local Government, ante, n. 53, at 302 , per Lord Jenkins. See also Washer, ante, n. 55

95 Canada: R.S.C. 1952, c. 152, s. 46(1): Newfoundland: R.S.N. 1952, c. 258, s. 47 (1) ; Nova Scotia: R.S.N.S. 1954 . c. 295 , s. $46(1) ;$ New Brunswick: R.S.N.B. 1952, c. 124, s. 44(1); Quebec: R.S.Q. 1964 , c. 141, s. 131 ; Ontario: R.S.O. 1960, c. 202, ss. 74 (1), $34(9), 65(5)$ and 73; Manitoba: R.S.M. 1954, c. 132, s. $47(1)$; cf. Saskatchewan: S.S. 1966. c. 83. s. 9; Alberta: S.A. 1957, c. 38, s. 43.

on [1966] 1 O.R. 473 .

gi R.S.C. 1952 , c. 152.

no Id., s. 19 .

oo Ante, n. 96, at 479. 
Such statutes as the Dominion one are able to produce this result through arbitral tribunals which the courts nonetheless have held are not rendered compulsory under the legislation. However, if the parties themselves do stipulate arbitration as their chosen instrument for settling disputes, the legislation then has the effect of restricting the parties to this one remedy, which forms an entirely comprehensive code for resolving any difficulties that may arise out of the application of the terms of the agreement. No outside influences are necessary. The Legislature intended that its enactment and the administrative provisions it contains should be entirely self-sufficient, and implicit in such a view is a legislative intent to exclude extra-statutory relief and agencies from interfering with this exhaustive scheme for regulating those industrial relations within its limits. This also follows upon the reluctance of the courts to rule on matters for which the parties have established their own administrative machinery. ${ }^{100}$

If we may assume for the moment, therefore, that the courts cannot enforce directly the substantive terms of a collective agreement, ${ }^{101}$ may it then attain that same goal by relying on the individual contract of employment? In other words, are the courts able to circumvent their immediate lack of jurisdiction over the collective agreement itself by enforcing its terms through the medium of the employment contract? It is not disputed that in Nelsons Laundries Ltd. v. Manning ${ }^{102}$ it was held that a restrictive covenant in the collective agreement was also imported, by implication, into the service contract and that in $R e$ Grottoli and Lock \& Son Ltd. ${ }^{103}$ a similar result was reached with respect to vacation pay provisions in the collective agreement. The question remains, however, whether in arriving at this result the courts are not flying in the face of the statutes that provide otherwise.

Although the language of the labour-management enactments makes reference only to the collective agreement and appears, therefore, to take no cognizance of the individual service contract, in the presence of a comprehensive agreement binding on the same employer and employee there seems little need to continue to enforce the latter. But it is one thing to find that a collective agreement does not displace the contract of employment and quite another then to import into the hiring contract all the terms of that agreement. ${ }^{104}$ Despite the broad brush of the Le Syndicat judgment, for the purposes of terms of employment not within the general contract ${ }^{105}$ and of formulating certain extraordinary provisions in respect of any specific employee, the service contract may indeed be a very necessary adjunct to a collective agreement universally applicable in the unit. Nevertheless, to carry the concept of the service contract beyond this status of mere appendage and give to it the same substance as the collective agreement, would be

100 E.g., Caven v. C.P.R., ante, n. 27; Kuzych v. White, [1951) A.C. 585; Hume \& Rumble Ltd. v. Local 213 of International Brotherhood of Electrical Workers, ante, $n$. 48; Cummings v. H.E.P.C. of Ontario, ante, n. 78. But compare the following: McKinnon v. Dominion Coal Co. Ltd., 5 D.L.R. (2d) 481, where a claim for the recovery of wages which, it was alleged, were wrongfully reduced by the defendant after the wages which, it was alleged, were wrongfully reduced by the defendant after the
collective agreement had expired was considered; Wheaton v. Local 1598, Carpenters' collective agreement had expired was considered; Wheaton v. Local 1598, Carpenters'
Brotherhood, ante, n. 49; Doman's Transport Ltd. v. Building Materials, etc. Union, ante, n. 49.

102 Ante, n. 23, at 499-500 (W.W.R.); 543-5 (D.L.R.).

103 Ante, n. 26, at 256.

104 Ante.

105 Northcott, ante, n. 69. 
tantamount to asserting that the legislature intended the terms of an agreement to be enforceable both in accordance with the statute and by common law action before the courts. And yet, manifested by its language the intention of the legislature appears otherwise: the collective agreement is made binding upon the employer, the employees of the unit and the trade union; criminal prosecutions for its breach are provided; grievance procedures must be set out therein; and elaborate administrative apparati are established. The parties are given no alternative. They cannot leave the matter at large and hope thereby to be allowed to take their differences before the courts. The statutes require provision

for the final and binding settlement ... without stoppage of work, of all differences between the parties arising from the interpretation, application, administration or alleged violation of the agreement ...

and this leads one to re-echo those words of the Ontario Court of Appeal quoted earlier..$^{100}$

Inherent in the policy which forecloses this recourse to the courts is a philosophy that non-judicial administrative machinery may bestow more benefits on all concerned. These benefits comprehend the optimal means by which the legislative purpose may be realized and raise the fundamental issue of whether in this area of industrial relations the courts are not ill-suited to conduct the implementation of legislative policies.

The growth of trade unionism and of collective action by the industrial masses expressed the reaction of the nineteenth century to the almost religious fervour with which freedom of contract and laissez-faire were pursued by those powerful interests that then in essence ruled England and the United States. History discloses many strands forming the rope that bound the worker. Economically, the Industrial Revolution was in full stride; England led the industrial and mercantile world and the railways were already helping to transform the United States into the mighty giant we now know. Declining feudalism had long ago torn men from the secure confinement and warmth of a society founded on a person's station in life in which each discovered his specific rights and obligations. The Protestant Reformation with its emphasis on individual responsibility had accelerated this reaction away from concern for the community in favour of an accentuation of the individual in society. As economics became ever more divorced from religion and ethics, it formed increasingly an end in itself. To this ferment John Locke and a pre-occupation with property were added and the result was a victory for liberalism and its stress of the freedoms and rights of man in society. The law, of course, shortly came to reflect this desire of society to protect rights rather than enforce responsibility and with this atomistic view of man astride a community freed from mercantilism and State and Church controls in the market-place, little else was necessary for hoisting the standards of such concepts as laissez-faire, caveat emptor, etc. ${ }^{107}$

Throughout the last century and in the early part of this one, the law continued to reflect this economic philosophy. This was most ap-

106 Re Etmanski and Taggart Service Ltd., ante, n. 96.

107 See for example Bromke. The Labour Relations Board in Ontario; Tawney, Religion and the Rise of Capitalism, chs. IV and V. 
parent in the law of contract, and yet, the very basis of a viable contract had lain in the negotiation of its terms by two competent individuals with approximately equal bargaining strength, and in a desire not to disturb existing, and hence vested relationships upon which persons could be expected to act. But the rise of joint-stock companies and other forms of economic power destroyed one of these bases of freedom of contract. The negotiating strength of a powerful entity obviously made a mockery of equal bargaining positions and could not but leave the individual contractor in an unenviable economic situation. The consequences of this became apparent in the cases of insurance and common carriers, where a large company holding an oligopolistic or monopolistic position could adopt successfully a "take-it-or-leave-it" attitude with prospective patrons. Legislative action combined a variety of controls: statutory contractual terms, licensing requirements and other limits on the otherwise unfettered powers of these entities. But an unmoved judiciary, who seemed generally unwilling to surrender their unremitting effort on behalf of outdated concepts of contract, did little to remedy the situation thereby prompting this necessary reliance upon legislative action to restore a more proper balance.

In the field of labour law, however, matters were much worse. At stake was the livelihood, the very life-blood, of the worker and his family and thus the consequences of inequalities to be found in negotiating a contract between a lone employee and his more powerful master were bound to culminate in far more unjust and explosive situations. Reason might have demanded that in the negotiation of the terms of an employment contract the workers should be allowed to organize themselves into a group with a bargaining strength approximating that of their employer. In that way, the concept of freedom of contract would still be preserved but against a background of greater fairness and less exploitation. However all the familiar maxims and principles were not to be so easily budged. The courts failed to adapt themselves and the law to the modern social and economic scene and remained convinced of the efficacy of their anachronistic applications of the law. It is not difficult to understand, therefore, why an agency, which until the very moment of legislative reforms continued to regard trade unions as illegal entities ${ }^{108}$ and the agreements to which they were party as unenforceable, ${ }^{100}$ should have been wholly distrusted by the working man. The ultimate reaction that set in here as in other fields began the pendulum's swing back to the insight that contract and property rights merely formed other elements of the fabric of society which owed the much higher communal responsibility to the persons of which it was composed.

However, that the legislature, and not the courts, undertook to rectify the gross inequities that characterized the industrial relations of employer and employee in this earlier age, and that the judiciary failed to retain the necessary confidence of trade unions and their membership will not serve to sustain the conclusion that legislation intended to exclude the courts from adjudicating upon the terms of employment reached by the parties. The earlier discussion analyzed cases and labour enactments in

\footnotetext{
108 Russell v. Amalgamated Society of Carpenters and Joiners, ante, n. 8; Polakoff v. Winters Garments Co., ante, n. 8.

109 Young v. Canadian Northern Rwy. Co:, ante, n. 9.
} 
order to discover whether these alone might permit us to descry what jurisdiction, if any, was meant to be denied to the courts. Still, the underlying contest between the court and a non-judicial arbitral tribunal established by statute and contract cannot be ignored. In the dynamic technology and far from stable conditions of our present industrial society, a collective agreement for no matter how small a unit is not meant to be a permanent and unchanging fixture. Not only will its term of life be relatively short, but it is even likely that the parties may have prognosticated amendment of its provisions during that time. Automation provides one example only of that unceasing flux which demands constantly fresh and renewed appraisals of industrial labour conditions. Moreover, a prominent ingredient of our modern society is the close inter-relationships that knit companies and their work-forces more closely together. So, the unit bound by one collective agreement is greatly affected by the improved technology and the collective agreements in other units within the same industry and even within other sectors of the economy to which the employer is tied by the bond of economic inter-dependance. An agreement to be interpreted over a period of time and in which conditions are ever in flux must remain flexible, but this feature makes precise contractual language difficult indeed. Therefore, aware of these factors and mindful of the declared legislative policy of "settlement without stoppage of work of all differences between the parties" and of the evident boon to an economy that is not strife-torn by continual strikes and lock-outs, we may begin to understand that the painfully slow and laboured processes of the courts might not be conducive to the necessarily quick, responsive and knowledgeable resolution of disputes arising out of the provisions of a collective agreement.

Matters are not improved when it is imagined in what manner a court might resolve such a dispute. The Canadian experience with judicial treatment of its written constitution leads to fears that the courts would fail to distinguish the collective agreement from any private commercial contract only governing its contractors inter se. However, a collective agreement affects so many people outside its immediate ambit and relates to such countless variegated activities that its influences and effects extend far beyond the unit in which it binds. Moreover, it must be remembered that the legislation here gives a compulsory quality to collective agreements thereby tending to remove them from the field of purely private law. Thus, as with workmen's compensation, the fate of so large a proportion of the nation's people subjected to a narrow application of rules of interpretation and contract law might well be seriously harmed by thoughtless, though "principled", justice. Where the courts fail, the State and its legislatures have no alternative but to take the matter in hand. ${ }^{110}$

Unfortunately, because there is a profound issue of policy here, the courts are placed in somewhat of a dilemma. To have some understanding of how to interpret the public interest requires a measure of participation in, or at least descent into, "the tumult and the shouting" where the policies are formulated and interest groups vie for supremacy. But this is the very antithesis of what is demanded of a judge whose qualities of impartiality and objective distinterestedness place him above

110 Cf., Cunningham, Labour Relations Boards and the Courts, 30 C.J.E.P.S. 499, at 510. 
all this in Olympian aloofness. And yet, a knowledge of what public interest is seeking; an understanding of the economic, industrial and social setting in which parties to labour relations interact; a comprehension of the underlying purposes and function of the law and, in particular, the legislation in this field, are vital qualifications of the persons who are called upon to administer these statutory provisions. ${ }^{111}$

On the other hand, the arbitrators chosen by the parties, it is hoped, will be possessed of that greater knowledge of the industry and of the issues involved. In addition, one of the parties at least will have greater confidence in this tribunal than in the courts and, as a result, whatever decision is reached will more likely be acceptable to labour and thus less open to a charge of bias in favour of "vested interests". The summary and informal procedures of an arbitration are more conducive to prompt settlements of grievance disputes and this is further enhanced by the expertise which many arbitrators bring with them. ${ }^{12}$ These are only some of the advantages that accrue to arbitral tribunals and that have prompted their ubiquitous and voluntary incorporation into commercial contracts. In labour matters, their presence takes on a far less gratuitous character under the statutes and leads one back to the inevitable question: why should the legislature have troubled itself with this comprehensive scheme for the government of labour relations if it had intended merely to continue the ordinary law of contract and the principle that an arbitration clause cannot exclude the jurisdiction of the courts? Three provinces expressly deny any application of the Arbitrations Act operating there ${ }^{113}$ and the recent Etmanski decision, although it overtly holds only that the Ontario Arbitrations Act does not apply when the federal I.R.D.I. Act is involved, does state that the latter "Act provides completely" for the settlement of grievance ${ }^{114}$ and thereby implies that had there been a federal Arbitrations Act it too would have been excluded here. ${ }^{115}$

A very practical difficulty that must arise if the courts continue enforcing the terms of a collective agreement will be the possible presence of two conflicting conclusions reached on the one set of facts. As a subsequent action in a court of law would constitute neither an appeal nor an inquiry into the jurisdiction of the arbitral tribunal, the latter's decision would, in any case, still stand. As was perceived by Denning, L. J: in a case where the plaintiff had sought a judicial declaration on a question which had already been heard by the Minister of Health empowered by statute to determine "any question arising under these regulations", the identical matter to that before the Minister was now being presented to the Court for a rehearing. Yet the Court could not disturb the Minister's decision.

There would then be two inconsistent findings, one by the Minister and the other by the court. That would be a most undesirable state of affairs ... [The court] would be exercising a jurisdiction to 'hear and determine' which does not belong to it but to the Minister.110

111 See generally Arthurs, Challenge and Response in the Laws of Labour Relations, 2 U.B.C. Law Rev. 335; Comment, Section 301(a) and the Federal Common Law

112 Cf Labour Agreements, 75 Yale L.J. 877, at 881-2.

113 Ontario, s. 34(10); Manitoba, S.M. 1957, c. 36. s. 19(4); Allberta, s. 73(18).

114 Ante, n. 96, at 478 .

115 Ibid. But compare Carrothers, ante, n. 87, at 99-102 where authority to the contrary is discussed.

116 Healey v. Minister of Health, ante, n. 56, at 228. 
To argue that a court in its consideration of an employment contract is exercising a jurisdiction which at law belongs to it, and that this cause of action differs from the matter determined by the arbitral tribunal allows form to take precedence over substance. Undeniably the forms are not identical, but the facts must be. That comprises the very foundation of the court's belief that it is able to fill up that skeletal service contract. If the substance is not permitted to govern, Canada will find itself in the same dilemma as that which the United States unhappily cannot avoid. ${ }^{117}$ Whose decision is then to prevail? If the courts hold that the arbitral award must give way, that is tantamount to invalidating this very vital ingredient of the legislative scheme ${ }^{118}$ thereby overturning the constitutional supremacy of the legislature.

It is submitted, therefore, that the courts should not usurp the function of boards of arbitration over "the interpretation, application, administration or alleged violation" of the terms of the collective agreement. They, of course, retain their jurisdiction to confine these legislative delegates to their proper statutory competence, to operate within those areas specifically given to them by statute and to continue to adjudicate upon matters that the legislature has not denied to them. However, this conclusion raises the spectre of constitutional difficulties at the hands of section 96 of the British North America Act, ${ }^{110}$ which requires the Governor General to appoint "the Judges of the Superior, District, and County Courts in each Province". The question that must then confront the legislative authority is whether it is seeking to vest in an administrative agency powers that are of a judicial nature and are analogous to those exercised by superior, district or county courts.120 For what has been created are tribunals to interpret and enforce collective agreements. That agreement may not have been enforceable by a court prior to the enactment of modern legislation, but the taint of illegality that then produced this result never deprived a court of its competence over these agreements. Rather, the courts admitted their jurisdiction, but then considered that for certain reasons they were not the proper agency for enforcing these bargains. ${ }^{121}$ And so we are confronted with a contract that is binding upon certain persons and which the legislature has directed is to be sent to an extra-curial body for enforcement.

Here again are competing policies. This time, however, the courts are given the further support of the B.N.A. Act and thus with no little justification may demand to know in what way they have lost their power to enforce the collective agreement and the contract of employment incorporating its terms. The two may here be considered together, for in whatever way jurisdiction is denied to the courts, it may be admitted that in the past contracts of service have always been considered justiciable, and refusal to remedy a breach of a collective agreement has been based on its unenforceability, not on the court's absence of

11 Section 301 of their Labour Management Relations Act, 61 U.S. 156, 29 U.S.C. 185. expressly grants a cause of action upon the collective agreement and so inevitably begs the presence of conflicting decisions from different forums. Jaffe, ante, $n$. 58, at 1048ff; Sovern, Section 301 and the Primary Jurisdiction of the N.L.R.B., 76 Harv. L. Rev. 529, at 551ff; Comment, Section 301 (a) and the Federal Common Law of Labour Agreements, ante n. 111, at 881-2.

118 Ganz, ante, n. 51 , at 368 .

120 Labour Relations Board of Saskatchewan v. John East Iron Works Ltd., [1949] A.C. 134.

121 Young, ante, n. 9, and cases cited ante, n. 8. 
jurisdiction. ${ }^{122}$ And hence the words of Milvain, J. become very important indeed.

I have doubt of the gravest character as to whether the Province can set up a tribunal with power to interpret contracts and so settle a dispute between the contracting parties as to the proper construction to be placed on contracts which bind them. ${ }^{123}$

Here one finds the very core of the matter: can a statutory body be given exclusive jurisdiction over disputes arising out of contract. That legislation may validly remove a certain matter from, or redefine the jurisdiction of, a court referred to in section 96 is settled, but to take what has been removed and attempt to give it to a legislatively appointed official is quite another question. ${ }^{124}$ For, once carried out, the issue of whether that subject-matter is, or is analogous to, one over which such a court exercises its authority disappears; the answer is self-evident from its patent transfer to this new tribunal. ${ }^{125}$ Rather, it is the person receiving this jurisdiction and his capacity to exercise it as a non-judicial entity that is fundamental. ${ }^{126}$

Still, the nature of this arbitral body in which the parties have agreed to repose their trust and confidence and which has been charged with administering the rules and constitution governing the master-servant relationships in the unit does begin to bear a resemblance to that of any domestic tribunal treated by the courts as an administrative agency clothed with a well defined jurisdiction. It is no new phenomenon that power is most forcibly exercised through the group. But with the growing complexity of society, the ability of the lone individual to make his presence and influence felt has diminished. This factor cannot be divorced from an ever dwindling faith in that once familiar laissez-faire and free-market community to which reference has already been made, nor from the realization that one gains little protection from the ruthless application of this purely individualistic philosophy of life. Clubs have always exemplified this concept of an association of individuals formed to further some purpose held dear by all, be it social, political, or cultural, but although such organizations were generally outside those realms of commerce and property with which the courts were usually concerned, the presence of even these considerations was never sufficient reason for asking the judiciary to exercise its full role where the rights and obligations of members inter se were involved. So, for example, the Inns of Court and medical societies are instances of where a man's professional and economic capacity to earn a livelihood according to his own

\footnotetext{
122 In the John East case ante, $n$. 120. Lord Simonds uses the language of "exercising judicial power". Whether one adopts this phrase or the word "jurisdiction", the courts nevertheless take a position that underlines their unquestioned power over the collective agreement.

". a trade union might still be considered to be, at law, an illegal society incapable because of its illegality of maintaining an action in Court, and a collective agreement might still be considered to be, at law, in unreasonable restraint of trade and hence unenforceable": Nelsons Laundries Ltd. v. Manning, ante, n. 23, at 497-8 (W.W.R.); 542 (D.L.R.).

1*:3 Calgary \& Edmonton Corporation Ltd. v. B.A. Oil Co. Ltd., ante, n. 50, at 971

$12+$ A.G.B.C. v. McKenzie, |1965| S.C.R. 490, at 497 and 500 .

123 On this problem of analogous subject-matters. see Brooks v. Pavlick, [1964] S.C.R. 108; A.G. Ontario and Display Service Co. Ltd v. Victoria Medical Bldg. Ltd., [1960] S.C.R. 32; L.R.B. Saskatchewan v. John East Iron Works Ltd., |1949| A.C. 134; Reference re Adoption Act, [1938] S.C.R. 398; Dupont v. Anglis, [1958] S.C.R. 535; 0 . Martineau \& Sons Ltd. v. Montreal, 11932| A.C. 113.

120 The issue of whether the legislature has attempted to create a court within the purview of $s$. 96 of the B.N.A. Act is considered in Toronto v. York, $\mid 1938\}$ A.C. 415; Farrell v. Workmen's Compensation Board, [1962] S.C.R. 48, affirming 26 D.L.R. (2d) 185; Reference re Adoption Act, ibid.; Brooks v. Pavlick, ibid.; John East case ibid.
} 
wishes fell to be considered under the same principles, whether those powers were exercized over him by a domestic tribunal founded upon statute or he was deemed to be a party to the constitution or agreement to which he subjected himself as member of the association. ${ }^{12 i}$ In either case, of statute or agreement, the person placed himself within the framework of a constitution to which he had given his consent, express or implied, and which stipulated a domestic tribunal to adjudicate upon matters thereunder. The courts here refused to challenge the substantive decisions of these tribunals and thus paid no heed to the jurisdiction which they were refusing to exercise. Again, only the procedural and jurisdictional questions were taken to be within their competence. At present, employers, professional men, employees, etc. have established similarly independent and individual associations as a form of self-regulation and mutual protection and in so doing each group has thereby sheltered itself to a large extent from the watchful eye of the courts. However, there is nothing inherent in such an association which demands that its membership be homogeneous and uniform; it is only necessary that each consent to subjecting himself to the terms of the constitution of the group. Therefore, it requires little effort to characterize the collective agreement as binding upon employer, employee and trade union alike and as subjecting each to its terms and to the domestic arbitral tribunal established thereunder. An agreement of this nature is more than a mere contract, for it has as its principal object the formation of an association of persons bound by statute to abide by its provisions. It is thus something over which the courts have never claimed a substantive competence to interpret or enforce. ${ }^{128}$ Those tasks are left to the domestic tribunal created for that purpose by the parties. ${ }^{129}$

The character of the collective agreement now re-fashioned by statute as the result of its confrontation with the problems of a modern industrial age ${ }^{130}$ was pointed out in Labour Relations Board of Saskatchewan v. John East Iron Works Ltd. ${ }^{131}$ where the constitutional authority of the appellant to order the respondent to reinstate a dismissed employee was in issue. There Lord Simonds stated:

\begin{abstract}
But his reinstatement, which the terms of his contract of employment might not by themselves justify, is the means by which labour practices regarded as unfair are frustrated and the policy of collective bargaining as a road to industrial peace is secured. It is in the light of this new conception of industrial relations that the question to be determined by the board must be viewed, and, even if the issue so raised can be regarded as a justiciable one, it finds no analogy in those issues which were familiar to the courts of 1867.132
\end{abstract}

Although a labour relations board admittedly qualifies more strongly as a tribunal outside the provisions of section 96 of the B.N.A. Act ${ }^{133}$ than does the board of arbitration charged with the duty of interpreting the words of an agreement by a process which strongly resembles a lis inter partes, still the Privy Council did not halt at an analysis of the

\footnotetext{
$12 \mathrm{i}$ See on this subject generally. Smith, Law of Associations; Lloyd, Law of Unincorporated Associations.

128 So, in Re Polymer Corporation and Oil, Chemical and Atomic Workers' Union, ante, n. 89, the arbitral tribunal was permitted, under the collective agreement, to award damages and the courts inquired only into its jurisdiction to do so.

129 See Comment by Professor Laskin, as he then was, 41 Can. Bar Rev., 446.

130 In Le Syndicat, ante, n. 10, Judson, J. discusses at $212-214$ the nature of the relationships created by this legislatively controlled and enforced agreement.

131 Ante, n. 120.

132 Id., at 150

133 Id., at $148-150$.
} 
tribunal in that case, but proceeded further in order to investigate the functions it performed. In that light, the arbitral bodies of all the statutory schemes merely furnish one other source of what legislators hope will assure industrial peace in a setting of economic well-being for the individual and society. Their function, therefore, though of narrower scope, is directed at those same ends which labour relations boards seek to achieve and so it is within the context of these legislative purposes, to be realized through collective bargaining and extra-curial processes, that "this new conception of industrial relations" must be viewed. In Dupont v. Inglis, ${ }^{134}$ where the duties of the Recorder under the Mining Act of Ontario were in issue, Rand, J. quoted approvingly from the John East case where the test for "analogy" was recited as

whether the subject-matter of the assumed justiciable issue makes it desirable that the Judges should have the same qualifications as those which distinguish the judges of superior or other courts.

His Lordship then proceeded:

The adjudications by the recorder and the Commissioner are not to be treated in isolation; the special elements of experienced judgment and discretion are so bound up with those of any judicial and ministerial character that they make up an inseverable entirety of administration in the execution of the statute. To introduce into the regular courts with their more deliberate and formal procedures what has become summary routine in disputes of such detail would create not only an anomalous feature of their jurisdiction but one of inconvenience both to their normal proceedings and to the expeditious accomplishment of the statute's purpose. ${ }^{135}$

Thus the functional interpretation of statutes, advanced earlier in the assessment of contesting administrative and judicial bodies, is proposed now in this constitutional setting. Which body can best attain the objects of the statute?-and in response to this the character of the tribunals and the nature of the questions to be adjudicated become vital and interdependent antecedents. ${ }^{136}$ So, an arbitral tribunal has been held capable of awarding damages under a collective agreement against one of its parties. ${ }^{187}$

In sum, therefore, it has been attempted here to analyze how the courts do and should regard the legal relationships of employer and employee as they arise out of the collective agreement both at common law and under the influence of modern legislation. Present enactments have drastically altered this particular sphere of labour-management relations; administrative remedies have become common and accepted; technology and social conditions are no longer of purely private concern. These form only part of the setting against which the manner and agency of enforcement of the terms of a.collective agreement have been discussed. ${ }^{138}$

\footnotetext{
134 [1958] S.C.R. 535

135 Id., at 541

136 See Farrell v. Workmen's Compensation Board, ante, n. 126, at 193-4 and 204 (D.L.R.)

137 Re Polymer Corporation and Oil, Chemical and Atomic Workers' Union, ante, $n$. 89.

138 For general and comprehensive reference on the whole subject of collective agreements, see Curtis, The Development and Enforcement of the Collective Agreement (1966); Carrothers, Collective Bargaining Law in Canada (1965).
} 